\title{
DIPLASIOLEJEUNEA MAYAYKUENSIS (LEJEUNEACEAE, MARCHANTIOPHYTA), A NEW LIVERWORT SPECIES FROM SOUTHERN ECUADOR
}

\author{
ALFONS SCHÄFER-VERWIMP, MARTIN NEBEL \& JOCHEN HEINRICHS
}

\begin{abstract}
A new epiphytic species of Diplasiolejeunea (Spruce) Schiffn. from the Amazonian region of southern Ecuador is described and illustrated. Diplasiolejeunea mayaykuensis Schäf.-Verw. \& Heinrichs, sp. nov. is characterized by ascending to squarrose leaves, narrowly ovate(-lanceolate) underleaf lobes with acute to subobtuse apices, well developed lobule teeth and lobules with strongly involute free margins. Morphologically, D. mayaykuensis closely resembles D. brunnea Steph. and D. cavifolia Steph. The locality is situated in the western escarpment of the Cordillera del Condor.
\end{abstract}

Key words: integrative taxonomy, Neotropics, Porellales

Alfons Schäfer-Verwimp, Mittlere Letten 11, 88634 Herdwangen-Schönach, Germany; e-mail: moos.alfons@kabelbw.de Martin Nebel, Staatliches Museum für Naturkunde Stuttgart, Rosenstein 1, 70191 Stuttgart, Germany; e-mail: martin.nebel@ smns-bw

Jochen Heinrichs, Systematic Botany and Mycology, Faculty of Biology, University of Munich (LMU), Menzinger Str. 67, 80638 Munich, Germany; e-mail: jheinrichs@lmu.de

\section{INTRODUCTION}

The pantropical genus Diplasiolejeunea (Spruce) Schiffn. includes some 65-70 morphologicallytypologically defined species. Centres of diversity of Diplasiolejeunea are the Neotropics and Africa; only a few species occur in Asia and Australasia (Schäfer-Verwimp 2006). Diplasiolejeunea is one of the few genera of Lejeuneaceae with one underleaf per leaf instead of one underleaf per leaf pair. It shares this character state with Colura (Dumort.) Dumort.; however, Colura usually produces sac-like lobules bearing a movable structure allowing the lobules to be closed (Heinrichs et al. 2012) and the lobule exceeds the lobe in length whereas the lobules of Diplasiolejeunea may be inflated but never sac like and never exceed the lobe length.

A recent molecular phylogenetic study allowed to identify several main lineages of Diplasiolejeunea and allowed for a classification into a Paleotropical subgenus Physolejeunea R. M. Schust. and the predominantly Neotropical subgenera Austrolejeuneopsis R. M. Schust. and Diplasiolejeunea
(Dong et al. 2012). This study also demonstrated incongruence between morphological and molecular variation and provided evidence for the presence of several still undescribed Diplasiolejeunea species. One of these species ('Diplasiolejeunea sp. nov. V', Dong et al. 2012) is here formally described, based on a herbarium specimen collected in southern Ecuador in the framework of the ABA-GAM project (Acceleration of Biodiversity Assessment - Gametophytes).

\section{DESCRIPTION OF THE NEW SPECIES}

Diplasiolejeunea mayaykuensis Schäf.-Verw. \& Heinrichs, sp. nov. (Subgen. Diplasiolejeunea)

Fig. 1

TYPE: ECUADOR, ZAMORA-CHINCHIPE, Amazonasgebiet südl. Paquisha, Kulturland bei Mayayku, epiphytisch an Solitär-Strauch; $850 \mathrm{~m}$; 3 $3^{\circ} 59.3^{\prime} \mathrm{S}, 78^{\circ} 38.9^{\prime} \mathrm{W}$, 30.1.2011, leg. A. Schäfer-Verwimp \& M. Nebel 32094 (HOLOTYPE: STU; ISOTYPES: GOET, JE, QCA). 
DESCRIPTION: Plants creeping on bark, small, in yellowish-green patches; shoots 10-15(-20) $\mathrm{mm}$ long and $1.4-1.7 \mathrm{~mm}$ wide. Stems closely adnate to substrate, (75-)80-95(-100) $\mu \mathrm{m}$ in diameter, in cross section with 3 medullary and 7 cortical cells, irregularly branched; branches widely spreading, similar to main stems, of Lejeunea type. Leaves imbricate, \pm flat, horizontally spreading, in younger parts of shoots loosely appressed to substrate, in older parts often ascending to squarrose, lobes broadly ovate, (700-)750-1000 $\mu \mathrm{m}$ long $\times 600-750 \mu \mathrm{m}$ wide, arching across the stem, margin entire. Cells of lobes in central part often regularly hexagonal, nearly isodiametric to somewhat longer than wide, ca 18-20 × (18-)20-24 $\mu \mathrm{m}$, marginal cells smaller and irregular in outline, (sub-)quadrate to pentagonal, $10-14 \times 12-15 \mu \mathrm{m}$, near lobe base elongate to rectangular, up to $20 \times 40 \mu \mathrm{m}$, sometimes 5-6 larger cells along insertion line, all cells (moderately) thick walled, without or with weak triangular trigones and a few ill defined intermediate thickenings. Chlorophyllous cells with oval chloroplasts, usually slightly smaller than the oil bodies; oil bodies $(2-) 3-6(-8)$ per cell, spherical or oval to fusiform, sharply crenulate, 2-3(-4) $\mu \mathrm{m}$ wide $\times 3-7(-9) \mu \mathrm{m}$ long. Ocelli scattered, 20-30 per leaf lobe, each containing a single, large glistening, homogeneous oil-body $($ ca $14 \times 16 \mu \mathrm{m})$, this large oil body occasionally accompanied by $1(-2)$ smaller ones, size of ocelli similar to surrounding cells, hence not visible in dried herbarium material. Lobule oblongobovate, $c a$ 350-420 $\mu \mathrm{m}$ long $\times 170-240 \mu \mathrm{m}$ wide, moderately inflated at least along keel but often throughout, ventral margin strongly curved, free margin strongly involute throughout, appearing under the microcsope as narrow dark stripe,
2-3(-4) cells wide. First tooth (median tooth) always well developed, usually 5-6 cells long and 2-3 cells wide at base, terminating in 2-3 superposed cells, with the tendency to be slightly twisted (see Fig. 1F), at least partly orientated (sub-)parallel to the stem. Second tooth (apical tooth) inflexed (as prolongation of the involute free margin of the lobule), rarely visible when lobule flattened, (2-)3-4 cells long and 2-3 cells wide, obtuse; hyaline papilla entally displaced. Cells of the lobule smaller than those of leaf lobe and more irregular in outline, from $10 \times 12 \mu \mathrm{m}$ to $18 \times 18 \mu \mathrm{m}$. Underleaves ca $4-6 \times$ stem width, up to $320 \mu \mathrm{m}$ long and $460 \mu \mathrm{m}$ wide apically, distant to subimbricate, deeply divided into two narrowly ovate(-lanceolate) lobes, sometimes for some distance with parallel sides, sinus acute to narrowly rounded, only $2-3(-4)$ cells from sinus to rhizoid disc; lobes up to $320 \mu \mathrm{m}$ long from base to apex (about 18-26 cells, from sinus to apex 14-22 cells), $120-140 \mu \mathrm{m}$ wide, mostly acute, occasionally subobtuse, ending with one cell, rarely with two superposed cells, cells usually (sub-)quadrate along margins, elongate to (sub-)rectangular in central part (up to 1.5-1.7 $\times$ as long as wide), from $14 \times 14 \mu \mathrm{m}$ up to 16 $\times 20 \mu \mathrm{m}$, apical cells usually isodiametric or wider than long. Asexual reproduction by discoid gemmae produced in great quantity on both surfaces of distal leaves; fully developed gemmae 6 cells long and $10(-11)$ cells wide [100-120 $\times$ $120-160(-190) \mu \mathrm{m}]$, consisting of $50-60$ cells, with three rhizoid initials.

Dioecious(?). Androecia not seen. Gynoecia on abbreviated lateral branches. Female bracts strongly complicate, $c a 1 / 3-1 / 2$ bifid, lobes nearly equal in shape and size, 450-500(-530) $\mu \mathrm{m}$ long and 150-200 $\mu \mathrm{m}$ wide, apex broadly rounded,

Fig. 1. Diplasiolejeunea mayaykuensis Schäf.-Verw. \& Heinrichs, sp. nov. A - upper part of plant, ventral view, 1.6 mm wide, $4 \mathrm{~mm}$ long, B - leaf lobe and stem with three subsequent underleaves, ventral view, with second tooth of lobule visible (scale bar $\mathrm{a}=300 \mu \mathrm{m}), \mathrm{C}$ - leaf lobe, dorsal view, with insertion line (scale bar $\mathrm{a}=300 \mu \mathrm{m}), \mathrm{D}-$ leaf lobe with lobule and underleaf, ventral view (scale bar $\mathrm{a}=300 \mu \mathrm{m}$ ), $\mathrm{E} \& \mathrm{~F}-$ details of lobule teeth, hyaline papilla stipulated (scale bar $\mathrm{b}=100 \mu \mathrm{m}$ ), $\mathrm{G}-\mathrm{apex}$ of two underleaves (scale bar $\mathrm{b}=130 \mu \mathrm{m})$. $\mathrm{H}$ - oil body, $4 \times 7 \mu \mathrm{m}, \mathrm{J}-$ cell structure of underleaf $(\mathrm{scale} \mathrm{bar} \mathrm{b}=130 \mu \mathrm{m}), \mathrm{K}-$ female bracts and bracteole (scale bar $\mathrm{b}=450 \mu \mathrm{m}$ ), $\mathrm{L}$ - female bracteole (scale bar $\mathrm{b}=130 \mu \mathrm{m}$ ), $\mathrm{M}$ - cells of central central leaf lobe, with oil bodies and chloroplasts (scale bar a $=25 \mu \mathrm{m}$ ), $\mathrm{N}$ - propagule, $105 \times 130 \mu \mathrm{m}, \mathrm{O}$ - perianth with bracts and bracteole, perianth $1.1 \mathrm{~mm}$ long, $620 \mu \mathrm{m}$ wide, $\mathrm{P}$ - capsule valves, flattened, with elaters (scale bar a = 400 $\mu \mathrm{m}$ ), Q - elater, $240 \times 16 \mu \mathrm{m}, \mathrm{R}-$ outer side of capsule valve, $210 \times 340 \mu \mathrm{m}$. All figures from the holotype, drawn by ASV. 


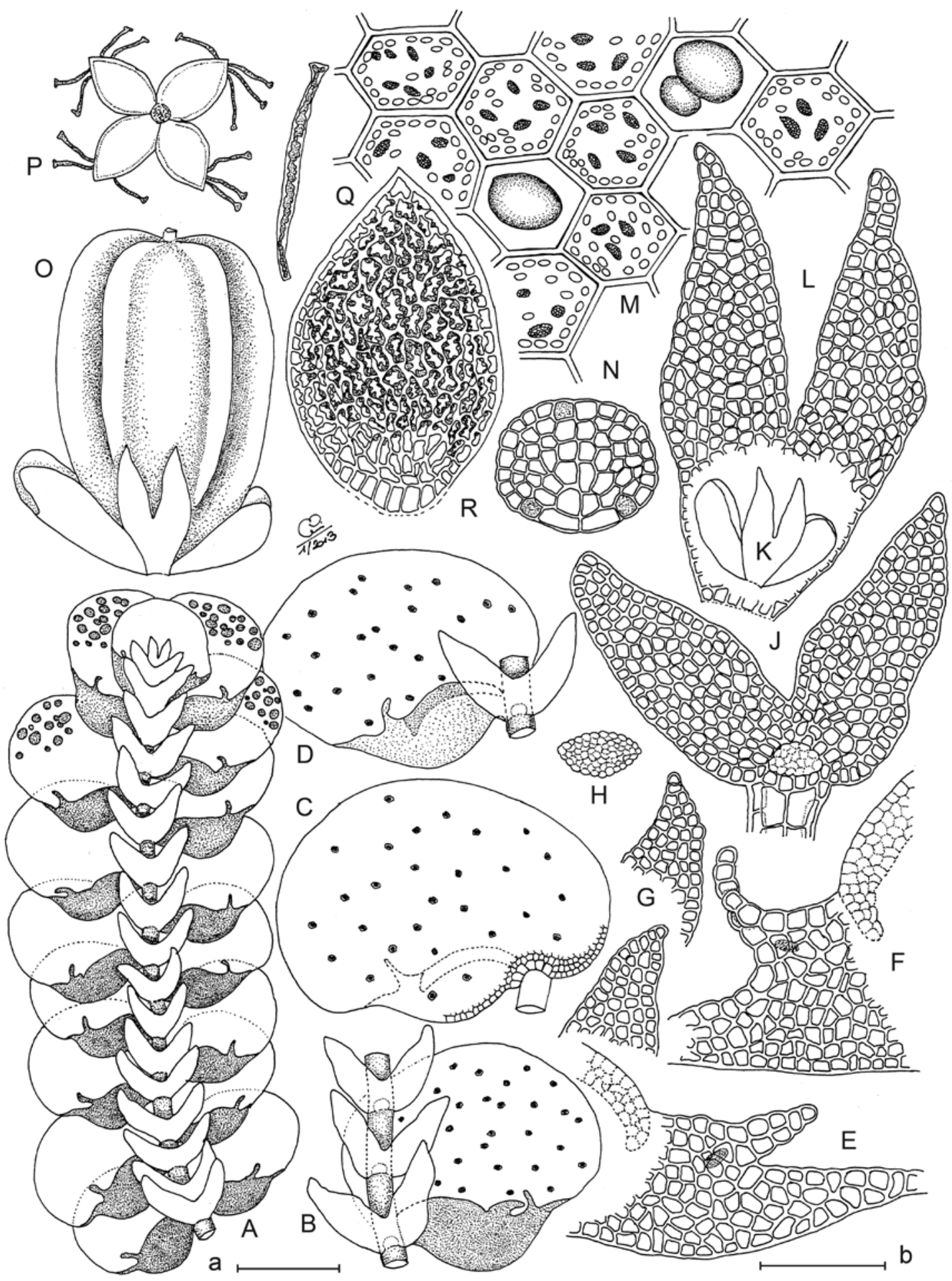


margin entire to slightly crenulate. Bracteoles oblong-lanceolate, $400-480 \mu \mathrm{m}$ long, $300 \mu \mathrm{m}$ wide, divided to $0.6-0.7$, sinus sharp, lobes narrowly triangular, acute to subobtuse, $300 \mu \mathrm{m}$ long and $130 \mu \mathrm{m}$ wide at base, margins partially slightly crenulate. Perianth rostrate, sharply 5-carinate, oblong obovate in outline, up to $1100 \mu \mathrm{m}$ long and $600-650 \mu \mathrm{m}$ wide, carinae running down nearly the entire length. Capsule short elliptical, $340 \mu \mathrm{m}$ long, $280 \mu \mathrm{m}$ wide, valves $330-340 \mu \mathrm{m}$ long and 200-210 $\mu \mathrm{m}$ wide, cells of outer side in upper $2 / 3$ with sinuose walls and strongly nodular and irregular thickenings, in lower part elongaterectangular with straight or only slightly sinuose walls and without nodulose thickenings. Elaters $\mathrm{ca}$ 4-5(-6) per valve, $240 \mu \mathrm{m}$ long and $16 \mu \mathrm{m}$ wide, obsoletely 1-spiral. Spores not seen.

ETYMOLOGY. The species epithet refers to the type locality in southern Ecuador.

\section{ECOLOGY AND DISTRIBUTION}

Diplasiolejeunea mayaykuensis was found on dead and living bark of a solitary shrub at the edge of a cultivated field near the village Mayayku in southern Ecuador in the western escarpment of the Cordillera del Condor. The bedrock consists of Zamora batholith, a granitoid rock (Spikings et al. 2001). Currently the species is known only from the type locality, however, further localities may be discovered when more field work is done in the region. According to the observed growing preferences, D. mayakuensis seems to be a a sun epiphyte and a pioneer which may have its natural habitat in the canopy of rain forests. Only a few associated species were observed in the type collection, namely the liverworts Frullania riojaneirensis (Raddi) Ångstr. and Frullania kunzei (Lehm. \& Lindenb.) Lehm. \& Lindenb., the lichen Leptogium sp. as well as an unidentified crustaceous lichen. On neighbouring shrubs and trees grew, among others, Metzgeria lechleri Steph., Orthostichidium quadrangulare (Schwägr.) B. H. Allen \& Magill, Dicranolejeunea axillaris (Nees \& Mont.) Schiffn., and Schoenobryum rubricaule (Mitt.) Manuel.

\section{DISCUSSION}

DELIMITATION OF D. MAYAKUENSIS FROM

\section{MORPHOLOGICALLY SIMILAR SPECIES}

The new species was already tentatively recognized in the field (by ASV) by its unique combination of morphological characters: (1) narrowly ovate(-lanceolate) (not triangular) underleaf lobes with acute to subobtuse apices; (2) yellowish green colour with broadly ovate leaf lobes up to $1 \mathrm{~mm}$ long and $750 \mu \mathrm{m}$ wide, presence of 20-30 scattered ocelli per lobe (visible only in fresh material); (3) two well developed lobule teeth; (4) lobules with narrowly but strongly involute free margins; (5) abundant production of discoid gemmae on upper and lower surfaces of leaves; (6) its habit with younger leaves loosely appressed to the substrate and older parts of the shoots with ascending to squarrose leaves.

Superficially, Diplasiolejeunea mayaykuensis resembles the two common species Diplasiolejeunea brunnea Steph. and D. cavifolia Steph. However, D. brunnea is best distinguished from D. mayaykuensis by its strongly appressed leaves and narrowly triangular underleaves; $D$. cavifolia by its lobule teeth. Diplasiolejeunea borhidiana Reyes and $D$. eggersii Pócs have underleaves most similar to D. mayaykuensis, however, both are readily distingiushed by lobule structure and lobule teeth (Reyes 1983, fig. 21; Tixier 1985, fig. 21, as D. magnistipulata; Pócs 2006, figs 1-16). Differential characters of $D$. mayaykuensis and morphologically or genetically similar species (Dong et al. 2012) are summarized in Table 1.

\section{INVESTIGATING THE LIVERWORT FLORA OF SOUTHERN ECUADOR}

Several new taxa of liverworts have been described from southern Ecuador only recently, namely Diplasiolejeunea erostrata Schäf.-Verw. and D. grandirostrata Schäf.-Verw. (Schäfer-Verwimp 2004), Cololejeunea stotleriana Gradst., Ilkiu-Borges \& Vanderpoorten (Gradstein et al. 2011), Cololejeunea kuciana Pócs \& Schäf.-Verw. (Pócs \& SchäferVerwimp 2012), Archilejeunea nebeliana Gradst. \& Schäf.-Verw. (Gradstein \& Schäfer-Verwimp 


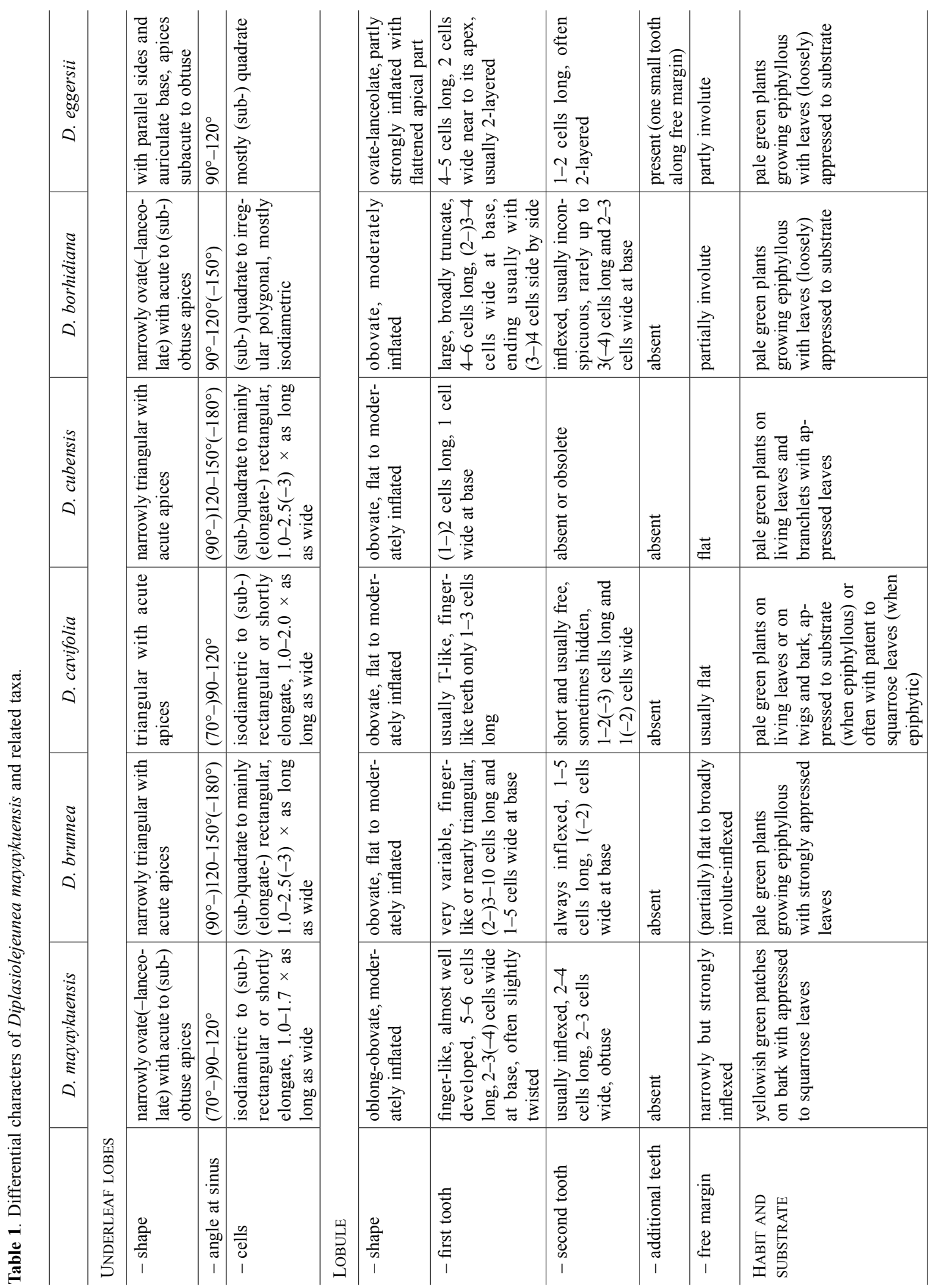


2012), Lobatiriccardia oberwinkleri Nebel, Preussing, Schäf.-Verw. \& D. Quandt (Preussing et al. 2010), Leptoscyphus autoicus (Engel \& Gradst.) Vanderpoorten \& Gradst. (Engel \& Gradstein 2003, as Physotheca), Plagiochila cucullifolia var. anomala Heinrichs \& Gradst. (Heinrichs et al. 2003) and Odontoschisma engelii Gradst. \& Burghardt (Gradstein \& Burghardt 2008). Recent fieldwork in southern Ecuador between 2003 and 2012 and accompanying molecular studies revealed five new species of Diplasiolejeunea (Dong et al. 2012) of which one is described in the present study. Diplasiolejeunea mayaykuensis adds to growing evidence that the liverwort flora of Southern Ecuador is still incompletely known, although more than 400 liverwort species were already recorded, indicating that southern Ecuador has the most diverse liverwort flora of the country (Schäfer-Verwimp $\&$ Nebel, in prep.).

ACKNOWLEDGEMENTS. Fieldwork in Ecuador by ASV and $\mathrm{MN}$ in the framework of the ABA-GAM project was supported by the German Research Foundation (grant LE 1826/4-1).

\section{REFERENCES}

Dong S., SchÄFER-Verwimp A., MeINECKe P., FELdBERG K., Bombosch A., Pócs T., Schmidt A. R., Reitner J., SCHNEIDER H. \& HEINRICHS J. 2012. Tramps, narrow endemics and morphologically cryptic species in the epiphyllous liverwort Diplasiolejeunea. Molec. Phylogenet. Evol. 65: 582-594.

Engel J. J. \& Gradstein S. R. 2003. Physotheca Engel \& Gradst., a new genus of Hepaticae from Ecuador, belonging to a new subfamily Physothecoideae Engel \& Gradst. Taxon 52: 763-773.

Gradstein S. R. \& BURGHARDT M. 2008. A new species of Odontoschisma (Marchantiophyta) from South America. Fieldiana, Bot. 47: 193-198.

GRADSTEIN S. R. \& SCHÄFER-VERWIMP A. 2012. A new species of Archilejeunea (Spruce) Schiffn. (Lejeuneaceae) from Ecuador. Cryptog. Bryol. 33: 107-112.

Gradstein S. R., ILKIU-Borges A.-L. \& VANDERPOORTEN A. 2011. Habitat specialization triggers the evolution of unusual morphologies: the case of Cololejeunea stotleriana sp. nov. from Ecuador. Bryologist 114: 9-22.

Heinrichs J., Gradstein S. R., Groth H. \& Lindner M. 2003. Plagiochila cucullifolia var. anomala var. nov. from Ecuador, with notes on discordant morphological and molecular variation in Plagiochila. Pl. Syst. Evol. 242: 205-216.

HeInRIChs J., DONG S., Yu Y., SchÄFER-VERWIMP A., PÓcs T., FELDBERG K., HeNTSCHEL J., SCHMidT A. R. \& SCHNEIDER H. 2012. A 150-year old mystery solved: Transfer of the rheophytic endemic liverwort Myriocolea irrorata to Colura. Phytotaxa 66: 55-64.

Pócs T. 2006. New or little known epiphyllous bryophytes, X. On two Neotropical Diplasiolejeunea species. Bryologist 109: 408-414.

PócS T. \& SCHÄFER-VERWIMP A. 2012. Cololejeunea kuciana (Lejeuneaceae, Marchantiophyta), another new species from southern Ecuador. Polish Bot. J. 57: 51-53.

Preussing M., Olsson S., Schäfer-Verwimp A., WiKKETT N., Wicke S., QuANDT D. \& NebEL M. 2010. New insights in the evolution of the liverwort family Aneuraceae (Metzgeriales, Marchantiophyta), with emphasis on the genus Lobatiriccardia. Taxon 59: 1424-1440.

REYes D. M. ['1982'] 1983. El género Diplasiolejeunea en Cuba. Acta Bot. Acad. Sci. Hung. 28: 145-180.

SCHÄFER-VERWIMP A. 2004. The genus Diplasiolejeunea (Lejeuneaceae, Marchantiopsida) in the tropical Andes, with description of two new species. Cryptog. Bryol. 25: 3-17.

SCHÄFER-VERWIMP A. 2006. A new species of Diplasiolejeunea (Lejeuneaceae, Jungermanniopsida) from Sumatra, and a key for the genus in Asia. Herzogia 19: 239-244.

SPIKINGS R. A., WinkLer W., SEWARD D. \& HANDLER R. 2001. Along-strike variations in the thermal and tectonic response to the continental Eucadorian Andes to the collision with hetrogeneous oceanic crust. Earth and Planetary Science Letters 186: 57-73.

TIXER P. 1985. Contribution à la connaissance des Cololejeunoideae. Bryophyt. Biblioth. 27: 1-439. 